ISSN: 1907-9931 (print), 2476-9991 (online)

\title{
UTILIZATION OF MULTITEMPORAL LANDSAT DATA FOR COASTLINE CHANGE ANALYSIS USING CANNY EDGE DETECTOR
}

\author{
Luhur Moekti Prayogo ${ }^{1}$, Zainul Hidayah ${ }^{2}$ \\ ${ }^{1}$ Master of Geomatics Engineering, Gadjah Mada University, Yogyakarta, 55281, Indonesia \\ ${ }^{2}$ Marine Science Study Program, Trunojoyo University of Madura, 69162, Indonesia \\ *Corresponding author e-mail: zainulhidayah@trunojoyo.ac.id
}

Submitted: 02 November 2020 / Revised: 21 April 2021 / Accepted: 03 June 2021

http://doi.org/10.21107/jk.v14i2.8924

\begin{abstract}
The development of remote sensing technology has experienced significant progress. This progress is marked by the availability of images of various resolutions with complete channels, open-source, and their development in various image classification techniques such as edge detection techniques. This study aims to examine changes in the coastline in Banmaleng Village, Gili Raja Island, Sumenep Regency using the Canny edge detection algorithm on multitemporal Landsat 7 and 8 imagery in 2005 - 2020. The edging process includes (a) minimize noise by applying a Gaussian filter, (b) determine the image intensity gradient, (c) apply non-maximum emphasis to eliminate spurious responses to objects, (d) define multiple thresholds for determining potential image edges, (e) Track edge hysteresis by pressing all other weak edges that are not connected to firm edges. Canny edge detection produces sharp edges to analyze coastline changes quite well. Every five years, the coastline of Banmaleng Village experienced shifting from 0,4 to 2,3 meters in several areas.
\end{abstract}

Keywords: Edge Detection, Landsat, Coastline, Canny Algorithm, Gili Raja

\section{INTRODUCTION}

Coasts are one of the most dynamic habitats on earth. The shape of the coast is influenced by natural forces, and in many places, it responds strongly to changing environmental conditions. In a broader definition, the coast terminology often interchanges with coastline and seashore (Ongkosongo, O. S. R., 1989; Anggraini et al., 2017). Coastline change over time is an interesting event to study. Triatmodjo (2012) states that the coastline is a line that forms the boundary between the land and the ocean, which is influenced by tides and prone to erosion and sedimentation. Ginting \& Faristyawan (2020) stated that the coastline position, which is the boundary line between land and water areas, is very complex due to the many interactions between sea, land processes. Moreover, Liu \& Jezek (2004) mention that knowledge related to coastlines is needed as a basis for interpreting the character of coastal and marine resources.

The development of technology in various fields in line with the advance of science. Information technology and computerization play an essential role in this development, for example, is the remote sensing technology (Prayogo \& Basith, 2020). Based on Lillesand et al., (2008) and Danoedoro (2012), remote sensing is the science or art of obtaining information on objects on the earth's surface using instruments or sensors without direct contact with the observed object. The use of this technology is closely related to the mapping field to solve various problems. In the discipline of earth science and geography, remote sensing technology is notably needed. One of the techniques in remote sensing that has been experiencing significant development is the digital image classification technique.

Satellite images are the product of recording objects on the earth's surface by sensors consisting of spectral values. This value is a reflection value that represents the sensed object. These values can be simplified to form certain classes that represent the actual objects. This process is based on grouping image pixel values into the same class (Danoedoro, 2012). Among many pixel classification methods, edge detection is relatively simple and still undergo significant 
Jurnal Kelautan, 14(2), 91-99 (2021)

development. Edge detection is an image processing method to produce each object's edges in the image (Munir, 2019). The image's edges can be seen from the difference in the gray points ( $x$ and $y$ ) from neighboring points (Munir, 2019). In remote sensing, distinguishing two objects is very necessary because if only use color characteristics, the image classification process will not be maximized (Munir, 2019).Another benefit of edge detection is that it can reduce the amount of data when processed and can be used for change detection on the coastline (Munir, 2019). Research on edge detection has been carried out quite often, but its application in coastal and marine areas is still quite rare.

Research by Anggraini et al., (2017) used the filter edge detection method and the Normalized Difference Water Index (NDWI) on Landsat 7 and 8 images of 2000 and 2005 in the Ujung Pangkah area, Gresik Regency. The region has suffered abrasion area of 5.19 $\mathrm{km}^{2}$ and $11.35 \mathrm{~km}^{2}$ accretion.

Furthermore, Zhang et al., (2013) used the Object-Based Region Growing Integrating Edge Detection (OBRGIE) and Object Merging Index (OMI) methods on Landsat and SPOT 5 images to detect coastline changes. The research revealed that the Root Mean Square Error (RMSE) of SPOT image was ranged from 8-8,6 meter, whereas Landsat image produced larger RMSE value (16-16,4 meter). Besides, to increase edge detection accuracy in highresolution images, The Richer Convolutional
Features (RCF) method was used. This method was proven to increase edge detection results by $5 \%$ (Lu et al., 2018).

The coastline always changes due to sediment movement and erosion (Anggraini et al., 2017). Coastline change can be detected particularly on a small island. One of the islands, which experience coastline change, is Gili Raja Island of Sumenep Regency, East Java Province. The island consists of four villages, namely Banbaru, Banmaleng, Jate, and Lombang, and is still part of the Gili Genting District (Kementerian Kelautan dan Perikanan, 2012). According to its dynamic coastal processes, this island is vulnerable to sea-level rise, currents, waves, and abrasion, making the coastline is subject to change conditions at any time. This study aims to analyze coastline changes particularly in Banmaleng village using Canny Edge Detector. This algorithm was chosen because it has been tested to produce sharper and more precise edges compared to other edge detection algorithms.

\section{MATERIAL AND METHOD Research Location}

This research was conducted in Banmaleng village to be precise at $7^{\circ} 12^{\prime} 24.37^{\prime \prime} S$ and $113^{\circ} 45^{\prime} 14.36 " \mathrm{E}$. This island is located in the west side of Gili Raja Island. The coastline observed in this study is about 800 meters in lenght. Figure 1 shows the map of the research location in Gili Raja Island.

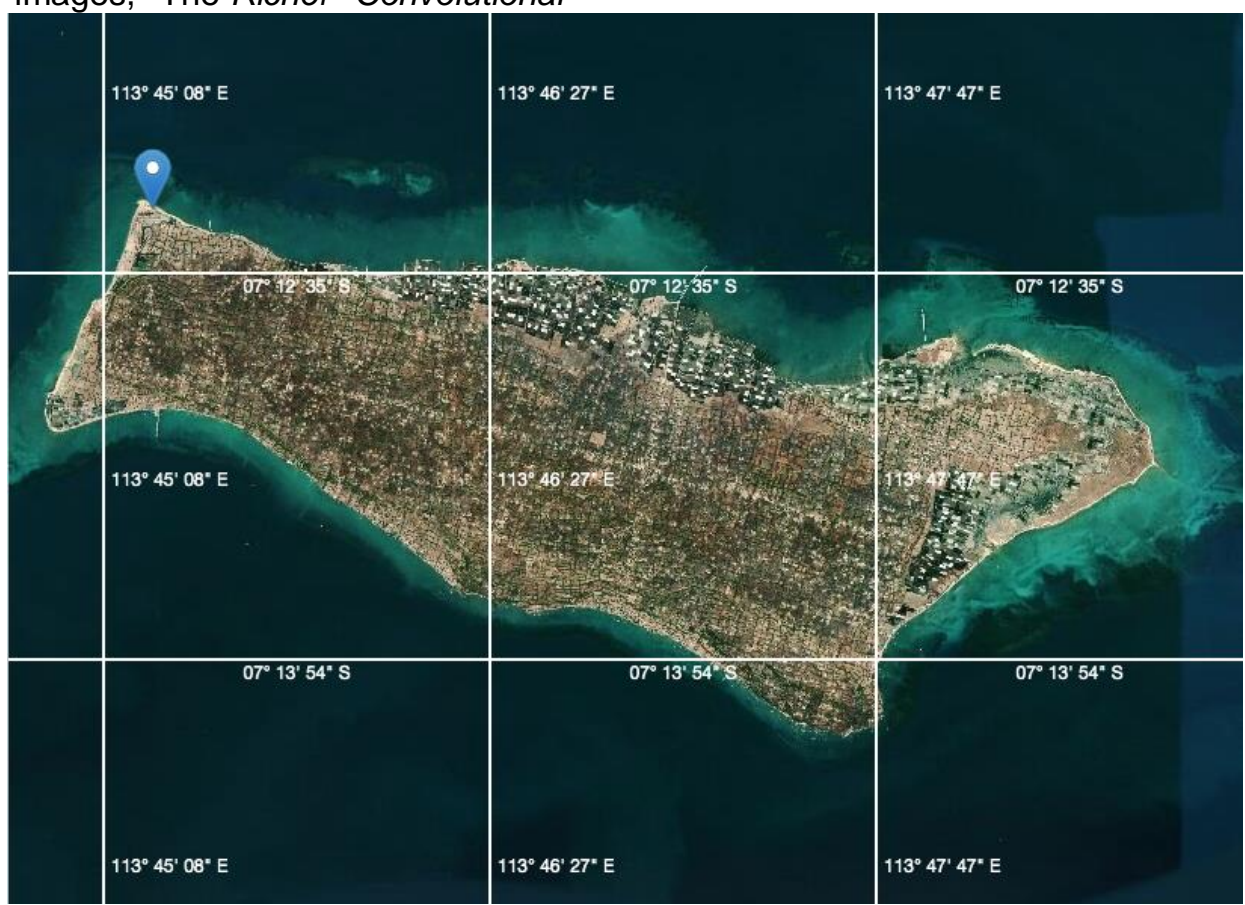

Figure 1. Research location map in Gili Raja Island, Sumenep Regency from ESRI World Imagery 


\section{Prayogo dan Hidayah, Utilization Of Multitemporal Landsat}

The Gili Raja Island beach's morphology is divided into two types: the rocky beach and sandy beach. Sandy beaches are the center of fishing activities, including ship repair, cultivation, and ship berthing. In comparison, the rocky beach is for residential areas. Gili Raja Island is included in the administrative area of Giligenting District, which has four villages. The following is the area of each village as shown in Table 1.

Table 1. Details of the area of Gili Raja Island village

\begin{tabular}{cc}
\hline Village & $\mathbf{K m}^{\mathbf{2}}$ \\
\hline Banbaru & 1,89 \\
Banmaleng & 3,26 \\
Lombang & 4,58 \\
Jate & 1,66 \\
\hline Total & $\mathbf{1 1 , 3 9}$
\end{tabular}

Source: (Kementerian Kelautan dan Perikanan, 2012)

\section{Landsat Imagery}

The data used in this study were Landsat 7 and 8 recorded in 2005 to 2020 . Landsat images are considered as the most useful medium resolution imagery with different acquisition times aims to analyze the occurrence of earth's surface. This image has the advantage of providing coverage of all parts of Indonesia and is available with various wavelengths (United States Geological Survey 2020a). In detail, the following are tables consist of Landsat 7 and 8 image specifications.

Table 2. Specifications for Landsat 7

\begin{tabular}{c|c|c}
\hline Bands & Wavelength (micrometer) & $\begin{array}{c}\text { Spatial Resolution } \\
\text { (meters) }\end{array}$ \\
\hline Band 1 - Blue & $0,441-0,514$ & 30 \\
\hline Band 2 - Green & $0,519-0,601$ & 30 \\
\hline Band 3 - Red & $0,631-0,692$ & 30 \\
\hline Band 4 - Near Infrared & $0,772-0,898$ & 30 \\
\hline Band 5 - Near Infrared & $1,547-1,749$ & 30 \\
\hline Band 6 - TIR & $10,31-12,36$ & 120 \\
\hline Band 7 - SWIR-2 & $2,064-2,345$ & 30 \\
\hline Panchromatic & $0,515-0,896$ & 15
\end{tabular}

Source: (United States Geological Survey, 2020a)

Table 3. Specifications for Landsat 8

\begin{tabular}{c|c|c}
\hline Bands & Wavelength (micrometer) & $\begin{array}{c}\text { Spatial Resolution } \\
\text { (meters) }\end{array}$ \\
\hline $\begin{array}{c}\text { Band 1 - Ultra Blue (coastal/ } \\
\text { aerosol) }\end{array}$ & $0,435-0,451$ & 30 \\
\hline Band 2 - Blue & $0,452-0,512$ & 30 \\
\hline Band 3 - Green & $0,533-0,590$ & 30 \\
\hline Band 4 - Red & $0,636-0,673$ & 30 \\
\hline Band 5 - NIR & $0,851-0,879$ & 30 \\
\hline Band 6 - SWIR 1 & $1,566-1,651$ & 30 \\
\hline Band 7 - SWIR 2 & $2,107-2,294$ & 30 \\
\hline Band 8 - Panchromatic & $0,503-0,676$ & 30 \\
\hline Band 9 - Cirrus & $1,363-1,384$ & $100^{*}(30)$ \\
\hline Band 10 - Thermal 1 & $10,60-11,19$ & $100^{*}(30)$ \\
\hline Band 11 - Thermal 2 & $11,50-12,51$ &
\end{tabular}

Source: (United States Geological Survey, 2020a)

In 2003, Landsat 7 experienced failure in the Scan Line Corrector (SLC), resulted in darksstrips or gaps in the images. As the consequence about $22 \%$ of the recorded image data was lost (United States Geological Survey, 2020b). To overcome these gaps, it is necessary to correct SLC first using other compatible data set. The following is the image recording date information used in this study: 
Jurnal Kelautan, 14(2), 91-99 (2021)

Table 4. Dates recording for Landsat 7 and 8 imageries

\begin{tabular}{c|c|c|c|c}
\hline Time & Imagery & Date Acquisition & Path & Row \\
\hline 2005 & Landsat -7 ETM+ C1 Level -2 & 16 September 2005 & 118 & 65 \\
\hline 2010 & Landsat -7 ETM+ C1 Level -2 & 22 Maret 2010 & 118 & 65 \\
\hline 2015 & Landsat -8 OLI/ TIRS C1 Level -2 & 03 Agustus 2015 & 118 & 65 \\
\hline 2020 & Landsat -8 OLI/ TIRS C1 Level -2 & 26 April 2020 & 118 & 65 \\
\hline
\end{tabular}

\section{Image Fusion}

Image fusion is the process of combining data from different data sources (Danoedoro, 2012). This technique is done so that the filtering process is getting better and sharper. There are various kinds of fusion methods in remote sensing, one of which is popular and used in this research is Principal Components Analysis (PCA) (Chavez \& Kwarteng, 1989). PCA is a fusion technique in images that is very simple compared to other methods, namely by changing the multivariate data with correlated variables into one with uncorrelated variables (PC1, PC2, PC3..,PCn) where $\mathrm{n}$ is the number of bands in Landsat images (Chavez \& Kwarteng, 1989; Y. Zhang, 1999; Schowengerdt, 2007; Leila Fonseca, Laercio Namikawa \& Lino Carvalho, 2014).

\section{Canny Edge Detector}

Canny edge detection is a technique for extracting structural information to reduce processed data (Canny, 1986). This process essentially work by applying a Gaussian filter so that the image becomes smoother as well as minimizes noise with the following equation (Canny, 1986; Deriche, 1987):

$g(x, y) D\left[\right.$ gauss $\left.(x, y)^{*} f(x, y)\right]$.

It is possible to combine the level of smoothness and edge designation into a convolution in one dimension with two different directions (vertical and horizontal) (Yadnya MS, 2014; Marques, 2011):

$H_{i j}=\frac{1}{2 \pi \sigma^{2}} \exp \left(-\frac{(i-(k+1))^{2}+(j-(k+1))^{2}}{2 \sigma^{2}}\right) ; 1 \leq i, j \leq(2 k+$
Then determine the image intensity gradient with the following equation (equation 3,4 ):

$G=\sqrt{G_{x}^{2}+G_{y}^{2}}$.

$\theta=$

$\operatorname{atan}^{2}\left(G_{y}, G_{x}\right.$

Where $\mathrm{G}$ can be determined by calculating the hypot and $a^{2} a^{2}$, then apply non-maximum emphasis to eliminate spurious responses to edge detection, define a double threshold to determine potential image edges, and Track edges with hysteresis: suppress all other weak edges that are not connected to strong edges (Canny, 1986; Deriche, 1987):

\section{Result}

\section{RESULT AND DISCUSSION}

Canny detection has a strict definition compared to other edge detections, so Canny detection results are reliable. The Canny algorithm has various general criteria for detecting object edges, including the detected edge of the operator to be accurately localized in the center, only marked once in each object (if possible, image noise is not recommended to create false edges) and to produce edges that are low error, the detection should capture as many edges of the object as possible. The technique used in Canny detection to obtain edge information according to requirements is the calculus function. The first derivative of Gaussian can explain this function. The following are the results of Canny edge detection on Landsat images for coastline extraction: 


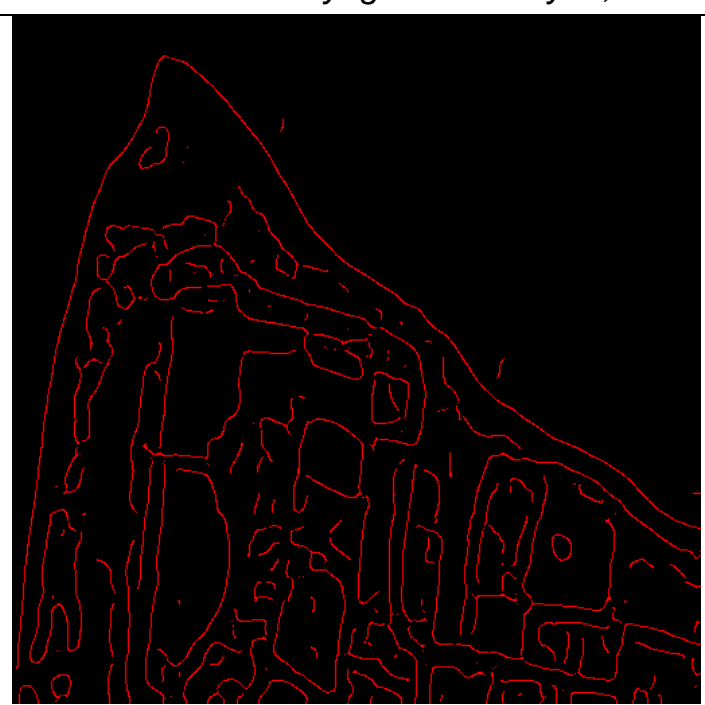

Landsat 7, 2005

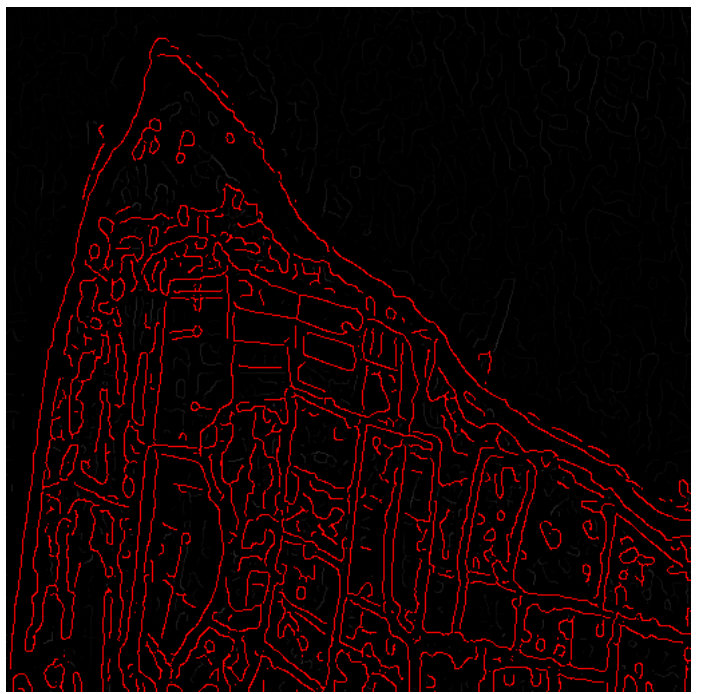

Landsat 8, 2015

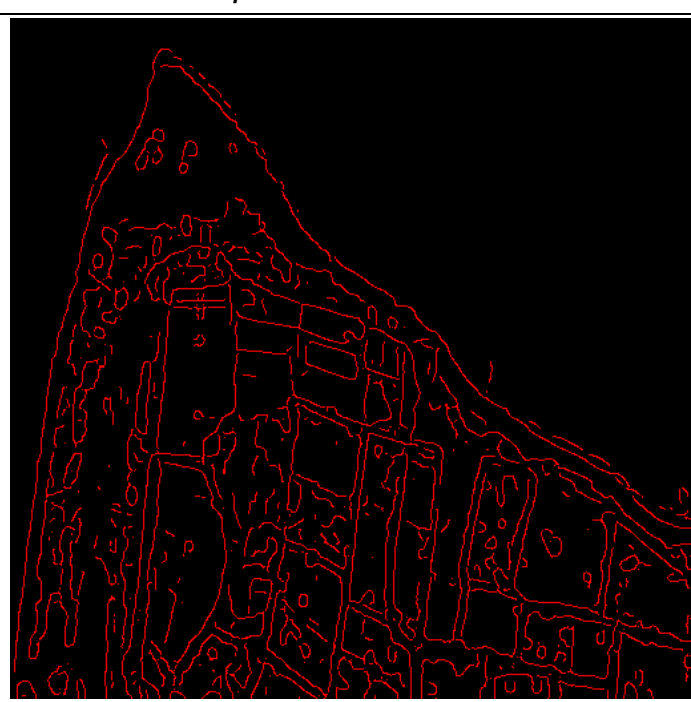

Landsat 7, 2010

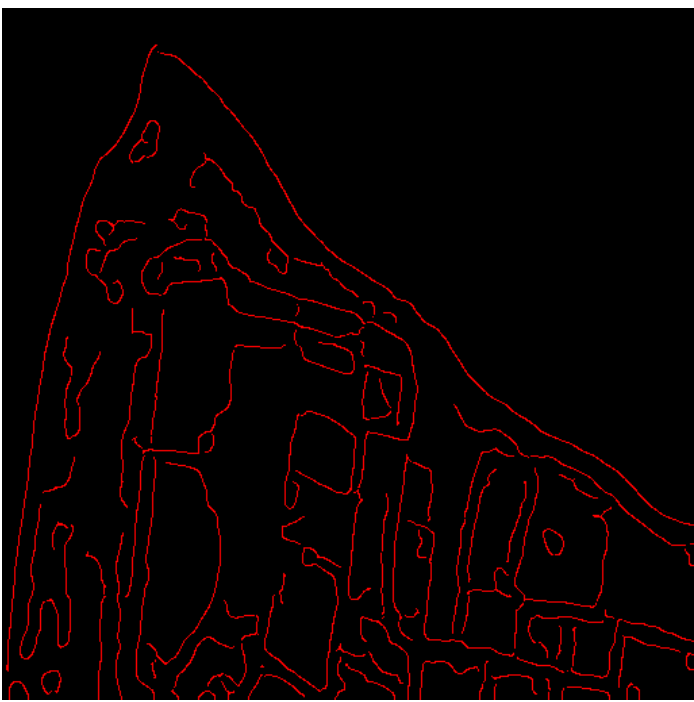

Landsat 8, 2020

Figure 2. Canny Edge Detector Results 2005 - 2020

The Gaussian Filter on the image serves to minimize noise so that the object's edges are easily detected by (Marques, 2011). This filter uses the kernel window, so the size of the kernel will affect the filter performance. Then find the intensity gradient of each image using four filters to detect horizontal, vertical, and diagonal edges of the blurred image (Canny, 1986; Deriche, 1987). This is done because, at the time of edge detection, each image's edges will point in various directions. The following is the appearance of the coastline in 2005, 2010, 2015, and 2020 in Banmaleng Village, Gili Raja Island, Sumenep Regency: 
Jurnal Kelautan, 14(2), 91-99 (2021)

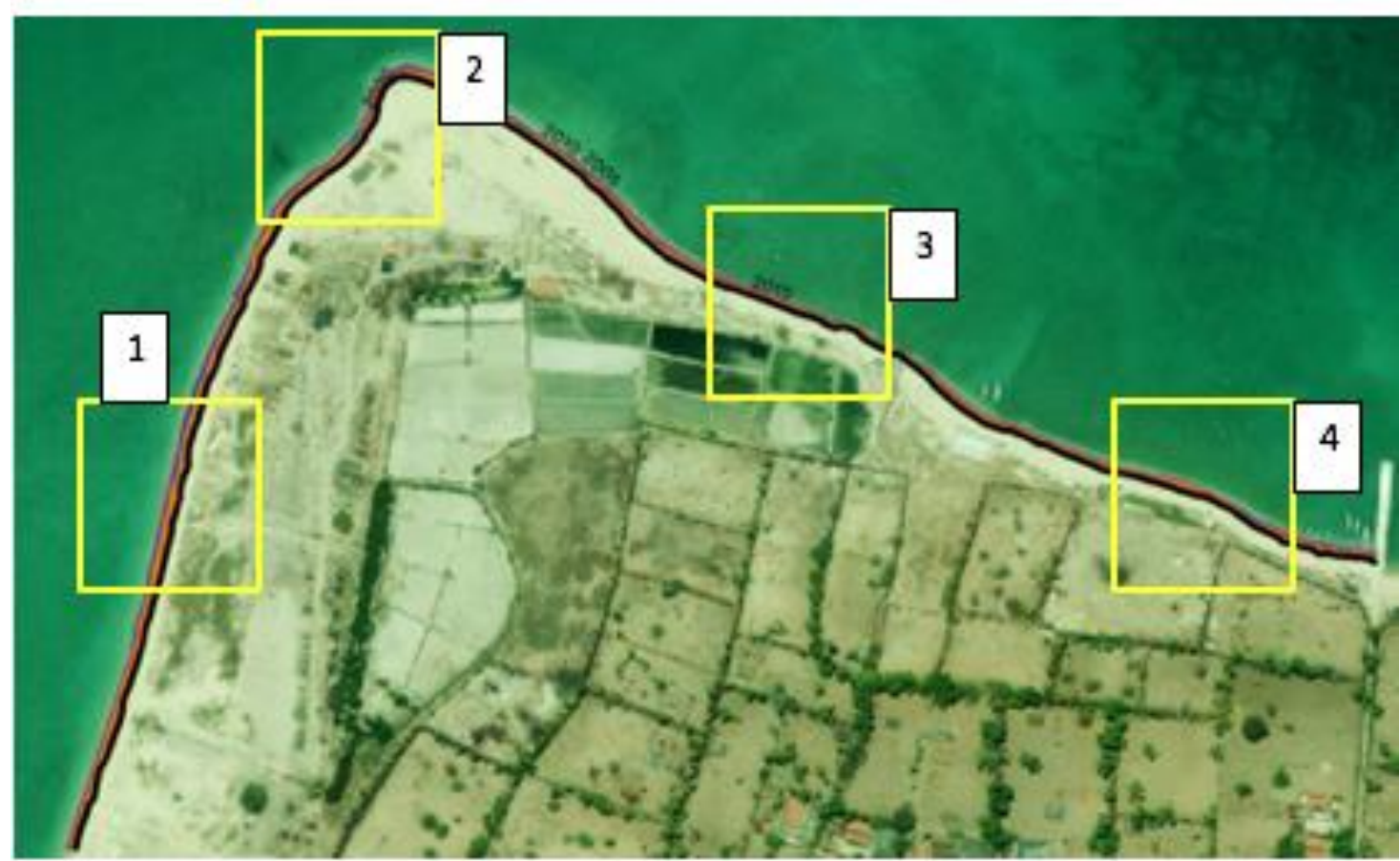

Figure 3. Coastline 2005, 2010, 2015 and 2020 with Basemap

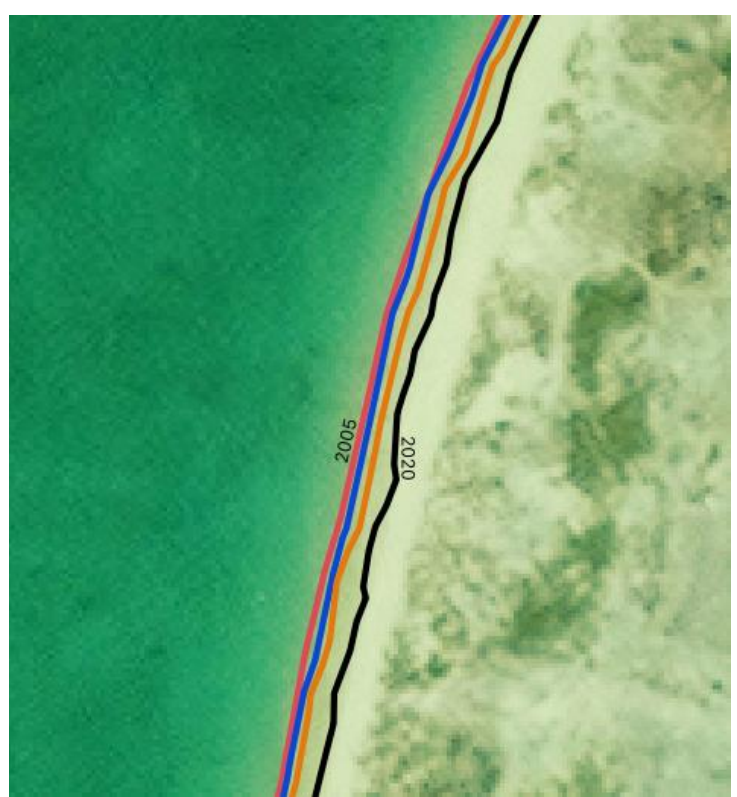

Sample Location 1

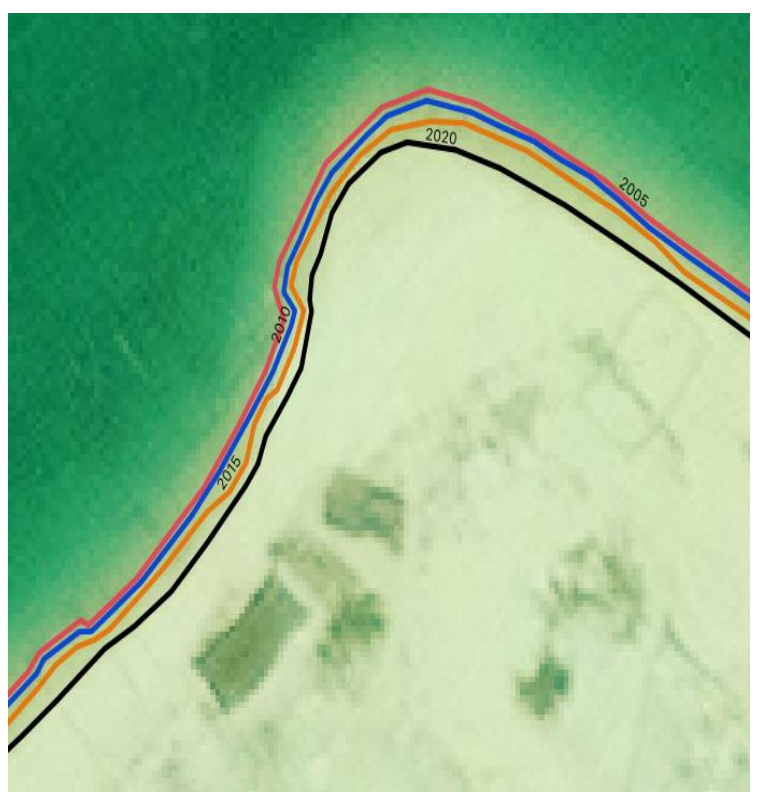

Sample Location 2 


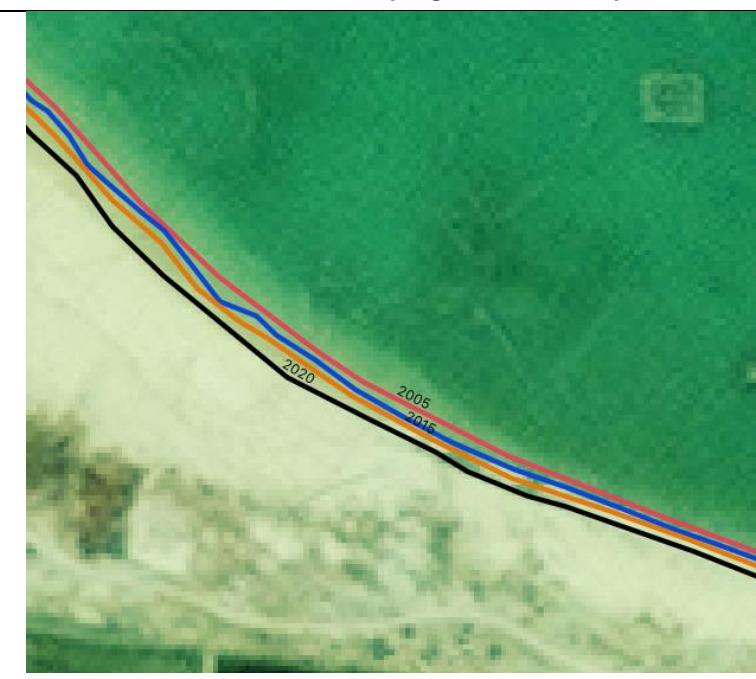

Sample Location 3

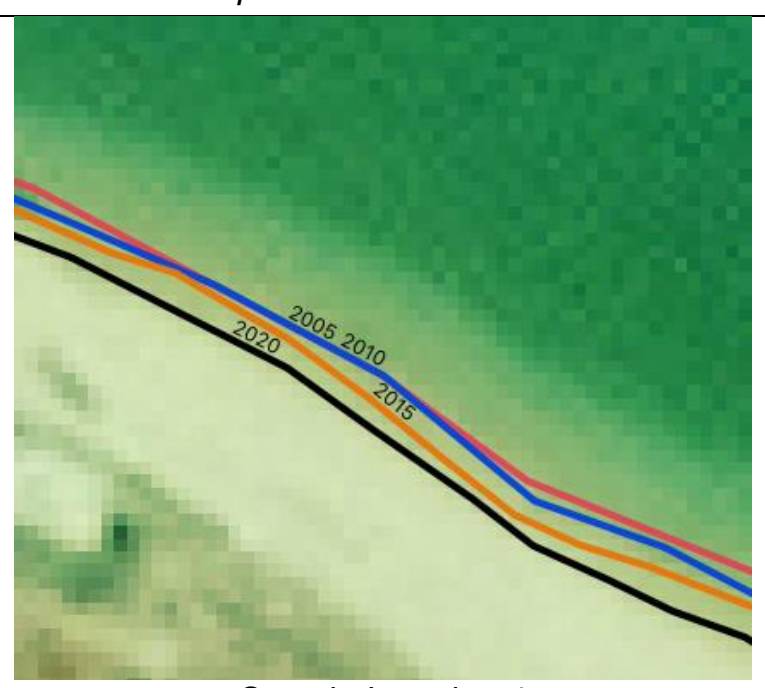

Sample Location 4

Figure 4. Sample of coastline locations in 2005, 2010, 2015 and 2020 with Basemap

According to the results above, in the last 5 years the coastline changed due to abrasion. In the first location, in 2005-2010, there was a shift of 0.92 meters; in 2010-2015, it was 0.84 meters, and in 2015-2020 there was a shift of 2.31 meters. Then at the second location, in 2005-2010, there was a shift of 0.80 meters, in $2010-2015$ of 1.02 meters, and in 2015-2020 of 1.34 meters. In the third location, in 2005-2010, there was a shift of 0.95 meters; in 2010-2015, it was 0.82 meters, and in 2015-2020 there was a shift of 0.97 meters. Then at the fourth location in 2005-2010, there was a shift of 0.72 meters; in 2010-2015, it was 0.46 meters, and 2015-2020 was 1.33 meters. The following is the shift information for each sample of the research location:

Table 5. Locations 1 and 2

\begin{tabular}{c|c|c}
\hline Time & $\begin{array}{c}\text { Coastline Shift (meters) } \\
\text { Location 1 }\end{array}$ & $\begin{array}{c}\text { Coastline Shift (meters) } \\
\text { Location 2 }\end{array}$ \\
\hline $2005-2010$ & 0,92 & 0,80 \\
\hline $2010-2015$ & 0,84 & 1,02 \\
\hline $2015-2020$ & 2,31 & 1,34 \\
\hline \multicolumn{2}{|c}{ Table 6. Locations 3 and 4 } & $\begin{array}{c}\text { Coastline Shift (meters) } \\
\text { Location 3 }\end{array}$ \\
\hline Time & 0,95 & 0,72 \\
\hline $2005-2010$ & 0,82 & 0,46 \\
\hline $2010-2015$ & 0,97 & 1,33 \\
\hline $2015-2020$ & &
\end{tabular}

\section{Discussion}

Besides the Gaussian filter, Canny edge detection for coastline change analysis is also done by thinning the image edges. This process is carried out to determine the change's location in the highest or sharpest intensity value to produce a more real and accurate image edge (Canny, 1986; Deriche, 1987). Analysis of coastline change is a basic research, where the results of it can be used to determine future coastal dynamic and management policies. Determination of image edges is the initial stage and often done in image segmentation applications. This step is carried out so that the analysis becomes easier in recognizing part of the particular object or the whole image.
Previous coastline change analysis was conducted by Yadnya MS (2014) in Senggigi Beach from 2006 to 2014 using Google Earth imagery and Canny edge detector. The results showed a reduction of the coastline by 1.5 meters in the last five years from 2009. Yasir et al., (2020) developed an edge detection technique for shoreline analysis in Qingdao from 2000 to 2019 using the Digital Shoreline Analysis System (DSAS) and Landsat imagery. The research resulted in accretion reaching 266.07 meters/year, 2391.85 meters, 124.47 meters/ year. The edge detection developed can also calculate the erosion in Qingdao Beach with an erosion magnitude of -142.55 meters/year, -1234.59 meters, -63.22 meters/year. Ginting \& Faristyawan (2020) was conducted in East Flores Island and West 
Adonara Island coasts, which have different beaches, namely rocky, sandy, and rocky cliffs. The data used are Sentinel 2, Landsat 5, and Landsat 8 imagery using Near-Infrared and Green bands to produce the best edges of the three types of beaches tested.

This study has demonstrated the ability of using medium resolution satellite images to detect coastline changes. Monitoring coastline is important for planning and development in the coastal region. Coastline changes will have an impact on environmental conditions and land use coastline, thus it requires optimal observation. The dynamic nature of coastal processes the coastline is never have stability either short-term or long term positions. The short-term changes of shoreline mostly caused by seasonal and periodical phenomena such as tides, waves and current. Whereas long-term changes are generally due to sea level fluctuations or changes in the coastal sedimentary budget ( Lo \& Gunasiri, 2014). Further investigation of previous studies mention that there are strong correlation between changes in coastal land use patterns and shoreline positions.

\section{CONCLUSION}

This research has shown the utilization of satellite images to detect coastline changes in a small island. The process of abrasion and sedimentation are predicted to be the cause of coastline changes in the study area. The Canny Edge Detector method produces sharp edges and is very useful to provide more convincing results in shoreline change detection.

\section{ACKNOWLEDGMENTS}

The author would like to thank the United States Geological Survey (USGS) for providing opensource Landsat image data so that the authors can use it in research.

\section{REFERENCES}

Anggraini, N., Marpaung, S., \& Hartuti, M. (2017). Analisis Perubahan Garis Pantai Ujung Pangkah Dengan Menggunakan Metode Edge Detection dan Normalized Difference Water Index (Ujung Pangkah Shoreline Change Analysis Using Edge Detection Method And Normalized Difference Water Index). Jurnal Penginderaan Jauh Dan Pengolahan Data Citra Digital, 14(2), 65-78. https://doi.org/10.30536/j.pjpdcd.1017.v 14.a2545.

Canny, J. (1986). A Computational Approach to
Edge Detection. IEEE Transactions on Pattern Analysis and Machine Intelligence, 8(6), 679-698. https://doi.org/10.1109/TPAMI.1986.476 7851.

Chavez, P. S., \& Kwarteng, A. Y. (1989). Extracting spectral contrast in Landsat Thematic Mapper image data using selective principal component analysis. Photogrammetric Engineering \& Remote Sensing, 55(3), 339-348.

Danoedoro, P. (2012). Pengantar Pengindraan Jauh Digital. In Benedicta Rini W (Ed.), Penerbit ANDI (1st ed.). Penerbit ANDI. $397 \mathrm{hlm}$.

Deriche, R. (1987). Using Canny's criteria to derive a recursively implemented optimal edge detector. International Journal of Computer Vision, 1, 167-187. https://doi.org/10.1007/BF00123164.

Ginting, D. N. B., \& Faristyawan, R. (2020). Deteksi Tipe dan Perubahan Garis Pantai Menggunakan Analisis Digital Citra Penginderaan Jauh. GEOMATIKA, 6(1), $17-24$. https://doi.org/10.24895/jig.2020.261.977.

Kementerian Kelautan dan Perikanan. (2012). Pulau Gili Raja. Direktori Pulau-Pulau Kecil Indonesia. http://www.ppkkp3k.kkp.go.id/direktori-

pulau/index.php/public_c/pulau_info/467 3 (accessed January 18, 2021).

Leila Fonseca, Laercio Namikawa, E. C., \& Lino Carvalho, C. P. and A. P. (2014). Image Fusion for Remote Sensing Applications. 153-178.

Lillesand, T.M., Ki.efer, R.W., and Chipman, J. (2008). Remote Sensing and Image Interpretation, 6th edition (John Willey and Sons (ed.); 6th ed.). Oxford.

Liu, H., \& Jezek, K. C. (2004). Automated extraction of coastline from satellite imagery by integrating Canny edge detection and locally adaptive thresholding methods. International Journal of Remote Sensing, 25(5), 937958. https://doi.org/10.1080/0143116031000 139890.

Lo, K. F. A., \& Gunasiri, C. W. D. (2014). Impact of coastal land use change on shoreline dynamics in Yunlin County, Taiwan. Environments, 1(2), 124-136. https://doi.org/doi:10.3390/environments 1020124.

Lu, T., Ming, D., Lin, X., Hong, Z., Bai, X., \& Fang, J. (2018). Detecting building edges from high spatial resolution remote sensing imagery using richer convolution 


$\begin{array}{lrlr}\text { features network. Remote Sensing, } & 20(10), & 2003-2014 . \\ 10(1496), & 1-19 . & h t \text { hs://doi.org/10.1080/0143116992123 } \\ \text { https://doi.org/10.3390/rs10091496. } & 17 .\end{array}$

Made Sutha Yadnya, R. N. I. (2014). Analisa Perubahan Garis Pantai Senggigi Menggunakan Pengolahan (GIS) Citra Satelit Pada Matlab. Dielektrika, 1(2), 131-135.

Marques, O. (2011). Practical Image and Video Processing Using MATLAB®. In I. John wiley \& sons (Ed.), Practical Image and Video Processing Using MATLAB®. https://doi.org/10.1002/9781118093467.

Munir, R. (2019). Segmentasi Citra. Program Studi Teknik Informatika Sekolah Teknik Elektronika. Institut Teknologi Bandung.

Ongkosongo, O. S. R., \& S. (1989). Pasang Surut (Pusat Penelitian dan Pengembangan Oseanologi (ed.)). Lembaga IImu Pengetahuan Indonesia. $257 \mathrm{hlm}$.

Schowengerdt, R. A. (2007). Remote Sensing: Models and Methods for Image Processing (3rd ed., Vol. 3). Academic Press.

Triatmodjo, B. (2012). Perencanaan Bangunan Pantai (Vol. 2). Beta Offset. $327 \mathrm{hlm}$.

United States Geological Survey (USGS). (2020a). Landsat Satellite Missions. https://www.usgs.gov/core-sciencesystems/nli/landsat/landsat-satellitemissions?qtscience_support_page_related_con $=0 \#$ qt-science_support_page_related_con (accessed January 19, 2021).

United States Geological Survey (USGS). (2020b). What is Landsat 7 ETM+ SLCoff data? usgs.gov/faqs/what-landsat-7etm-slc-data?qt-

news_science_products $=0$ \#qt-

news_science_products (accessed January 11, 2021).

Yasir, M., Sheng, H., Fan, H., Nazir, S., Niang, A. J., Salauddin, M., \& Khan, S. (2020). Automatic Coastline Extraction and Changes Analysis Using Remote Sensing and GIS Technology. IEEE Access, 8, 180156-180170. https://doi.org/10.1109/ACCESS.2020.3 027881.

Zhang, T., Yang, X., Hu, S., \& Su, F. (2013). Extraction of coastline in aquaculture coast from multispectral remote sensing images: Object-based region growing integrating edge detection. Remote Sensing, 5, 4470-4487. https://doi.org/10.3390/rs5094470.

Zhang, Y. (1999). A new merging method and its spectral and spatial effects. International Journal of Remote Sensing, 